\title{
In persona Christi Capitis: Agency problems when God is the principal
}

\author{
Clara E. Jace and Ennio E. Piano *
}

May 15, 2021

\begin{abstract}
The in persona Christi Capitis doctrine of the Roman Catholic Church guarantees the validity of its sacraments, irrespective of the personal morality of the priest who performs them. While this protects their value as metacredence goods, it seemingly opens the door to opportunistic behavior by the clergy. To balance out its institutional incentives, the Roman Catholic Church must rigorously screen its candidates for the priesthood. Historical evidence supports our hypothesis that the development of the in persona Christi Capitis doctrine was accompanied by marginal increases in the screening of seminarians, which may have been an optimal response to changing historical circumstances. Also consistent with our hypothesis, a cross-section of contemporary Christian denominations shows a correlation between a group's stance on sacramental theology and the strictness of its screening of candidates to religious ministry.
\end{abstract}

Keywords: Agency problems; Roman Catholic Church; Economics of religion

JEL Codes: D23; N8; Z12

\footnotetext{
${ }^{*}$ Clara: George Mason University, claraelizabethjace@gmail.com. Ennio: Middle Tennessee State University, ennio.piano@mtsu.edu. We would like to thank Joe Kaboski, Fr. Bob Gahl, Robert Tamura, Philip Booth, and other participants of the CREDO/Lumen Christi Seminar on Catholic Social Thought for their excellent comments. The suggestions of two anonymous referees is also gratefully acknowledged. The Graduate Student Paper Workshop at the Mercatus Center and numerous other colleagues lent their eyes, minds, and time to our project. We hope the remaining errors are only venial.
} 
"He who travels in the barque of St. Peter had better not look too closely into the engine-room."

-Ronald Knox

\section{Introduction}

There is considerable variation within Christianity concerning the role of ministers. For instance, some denominations - the Roman Catholic Church, the Orthodox Church, and, to a lesser extent, the Anglican and Lutheran churches - believe that only an agent of the church (e.g., a priest) may perform the sacraments. ${ }^{1}$ In these traditions, sacraments are understood as a visible means for conveying God's invisible grace. Other denominations believe that there can be no role for agents in this process: God supplies grace directly to the faithful.

This paper studies the implications of this doctrinal variation between Christian denominations for the organization of these groups' religious activities. ${ }^{2}$ We argue that the Roman Catholic (and other similar denominations') view of sacraments exposes the Church to agency problems. As an agent of the Church in the production and delivery of sacraments, the priest may affect the faithful's demand for the services of the Church. For instance, the faithful may be less willing to consume sacraments from the Church when they are exposed to information about scandalous behavior by priests. Churches that adopt a theological position that requires agents for the production and delivery of sacraments must adopt organizational practices and policies that differ significantly from denominations that do not.

Theologically, the in persona Christi Capitis doctrine explains why the Catholic priest is able to channel, through the sacraments, acts that only God has the power to perform, such as the forgiveness of sins or transubstantiation. For instance, the priest uses the first person during the celebration of sacraments and is understood as performing this role in persona Christi Capitis, that is, in the person of Christ the Head. The practical implication of this doctrine of the Catholic Church is that a priest's behavior has no impact on the validity of the sacraments he supplies. Thus, the faithful need not fear that the sacraments which they consume throughout their lives are not valid or do not contain God's gift of grace. This doctrine has two convenient properties. The faithful will spend fewer resources investigating the private mores of their priest, and the

\footnotetext{
${ }^{1}$ The sacrament of Baptism is an exception to this rule. While it is customary to have a priest baptize, this "rite of initiation" is so foundational to the Christian life that, in imminent danger of death, anyone with the right intention can administer a valid Baptism. Marriage presents another unique case. While it is preferred for a priest to be present, the spouses themselves are understood to be performing the sacrament through their vows and subsequent marital embrace.

${ }^{2}$ We follow Allen (1995) in assuming that theological commitments may constrain a religious group's choice between organizational forms.
} 
Church sees demand for its services go up. ${ }^{3}$

However, the doctrine may also encourage the priest to be marginally more sinful - a classic case of moral hazard. This may increase the number of scandals generated by agents of the Church, which reduces the value of the Church's brand. Thus we predict that the Church will accompany the introduction of this doctrine with an increase in its efforts to screen candidates to the priesthood and invest in other practices aimed at reducing the probability of scandalous behavior.

The historical evidence on the adoption and evolution of the doctrine is consistent with this prediction. During both the Donatist controversy of the fourth century and the Reformation of the sixteenth century, the Roman Catholic Church wrestled with clerical corruption, which threatened its position in the market for religion. In both cases, the Catholic Church adopted a twofold attack: 1) it reminded the faithful that despite bad priests, the sacraments they received were still valid (the in persona Christi Capitis doctrine), and 2) worked to reduce the overall level of corruption among its clergy (via seminary training and other forms of screening). ${ }^{4}$ Before an unmarried Catholic man can be ordained as a priest today, he must: 1) complete four years of College Seminary (studying philosophy); 2) four years of Major Seminary (studying theology); 3) pass various mental and physical health checks, including a family history analysis; and 4) follow the suggestions of his Spiritual Director for the deepening of his spiritual life.

We broadly contribute to a body of literature across theology, philosophy, and the social sciences on the uniqueness of the Roman Catholic Church and its persistence throughout time (Schmitt, 1996; Ferrero, 2011; Stark, 2003, 2007a; McGrath-Merkle, 2020; Gill, 2020). Our paper relates to the literature on the economics of religion and the economic analysis of the Roman Catholic Church, in particular (Iannaccone, 1998; Hull and Bold, 1989; Ekelund et al., 2002, 2004; Arruñada, 2009; Leeson, 2012). We further engage the literature that uses economics to study religious doctrines (Ault et al., 1987; Allen, 1995) and non-price competition between religious organizations (Leeson, 2013; Leeson and Russ, 2018). Our analysis complements that of Ekelund and Tollison (2011) which points out that "highly ritualized services" (i.e., sacraments) and "the existence of educated and sexually abstaining priests" signal to the faithful the quality of the metacredence goods supplied by the Roman Catholic Church.

\footnotetext{
${ }^{3}$ As this paragraph makes clear, the focus of our argument is the principal-agent relationship between the Church and its ministers, not the latter and God. Thus, readers should not interpret the title of the paper literally. As one anonymous referee pointed out correctly, the notion of a God-principal facing agency problems is inconsistent as long as one assumes (as mainstream Christian theology does) that God is all-knowing and thus cannot be negatively affected of asymmetric information. Instead, the title should be interpreted metaphorically in that ministers are agents of the Church, which is itself a representative of God on Earth.

${ }^{4}$ Although the Roman Catholic Church is traditionally referred to using the feminine pronouns, we will use "it" to remind the reader that we are analyzing primarily the natural aspects of the Church.
} 


\section{The in persona Christi Capitis doctrine}

The first formulation of the what would later be known as the in persona Christi Capitis doctrine emerged out of the Church's defense against the Donatist heresy in the early fifth century. ${ }^{5}$ The controversy arose after Emperor Diocletian's persecution led many Christians - including some bishops and priests - to apostatize in order to save their lives (Chapman, 1909). As the persecution waned, the Church announced that the apostates could be readmitted after a long period of penitence. Donatus, the bishop of Carthage, dissented. He argued that these traditores had, by apostatizing the one true faith, put themselves outside of the Roman Catholic Church and thus rendered their original baptism void. In order to rejoin the Church, they would have had to receive a second baptism. Donatus further argued that all priests and bishops who abandoned the faith lost the ability to confer any sacraments. Thus, all the sacraments they supplied since their apostasy would have been invalid.

The main defender of the Church against Donatism was another bishop (and future Saint) Augustine of Hippo. Contra Donatus' teachings about the nature of the priesthood, Augustine wrote:

[W]hether a man receives the sacrament of baptism from a faithful or a faithless minister, his whole hope is in Christ, that he fall not under the condemnation that 'cursed is he that placeth his hope in man.' (1995, p. 522)

He went so far as to argue that if - as Donatists held - a faithful minister could only pass his own spiritual gifts, then it would be far better to be baptized by an unfaithful minister, since he would then pass along the unmerited spiritual gifts of Christ. It was at this time that the Roman Catholic Church began to distinguish between the authority of the clergy and their personal morality, clarifying that its powers were inherent in the office of the priesthood as alter Christus (other Christ), such that their moral unworthiness did not affect the validity of the sacraments they administered. ${ }^{6}$

The Donatist controversy did not resolve this dispute once and for all. Debate concerning the nature of the priesthood and the sacraments was widespread during the Reformations of the sixteenth century. ${ }^{7}$ Indeed, it was in its response to the Reformation that the Roman Catholic Church most explicitly formalized its stance on the sacraments and the role of the priest in their

${ }^{5}$ We refer to Donatism as a "heresy" only to highlight its relationship to orthodox Catholic teaching, rather than our own view.

${ }^{6}$ That being said, there are accidental graces that might accompany sacramental graces. These accidental graces - while not primary - do arise from the personal holiness of the priest and receptivity of the faithful. We thank Fr. Bob Gahl and Brian Boyd for bringing this point to our attention.

${ }^{7} \mathrm{~A}$ brief timeline of the development of the in persona Christi Capitis doctrine and related events can be found in Table 1. 
production and delivery. The Council of Trent (1545) defined the sacraments as "outward signs of inward grace, instituted by Christ for our sanctification" (Council of Trent, 1547b). They listed seven sacraments: Baptism, Confirmation, Eucharist, Penance, Anointing of the Sick, Holy Orders, and Matrimony. Furthermore, the Roman Catholic Church reaffirmed its position on the priesthood:

But since in the sacrament of [holy orders], as also in baptism and confirmation, a character is imprinted which can neither be effaced nor taken away, the holy council justly condemns the opinion of those who say that the priests of the New Testament have only a temporary power... And if anyone should assert that all Christians without distinction are priests of the New Testament, or that they are all inter se endowed with an equal spiritual power, he seems to do nothing else than derange the ecclesiastical hierarchy (Council of Trent, 1547a).

Over four hundred years later, the Second Vatican Council restated the Church's position on the matter. In the official council documents, the in persona Christi Capitis doctrine is mentioned by name more frequently than ever before: five times in Lumen Gentium (Dogmatic Constitution on the Church), three times in Presbyterorum Ordinis (Decree on the Ministry and Life of Priests), and once in Sacrosanctum Concilium (The Constitution on the Sacred Liturgy). For example, Lumen Gentium links the doctrine with the liturgical rites and hierarchy found in both the Church of the East and the West:

[B]y means of the imposition of hands and the words of consecration, the grace of the Holy Spirit is so conferred, and the sacred character so impressed, that bishops in an eminent and visible way sustain the roles of Christ Himself as Teacher, Shepherd and High Priest, and that they act in His person (Pope Paul VI, 1964, p. 21).

Commenting on this passage, Thompson (1987) notes:

The footnote references to this passage are the fullest that are found in the Vatican documents in relation to the phrase in persona Christi. The references are not to the Scriptures or to the Council of Trent, but to the Fathers of the Church. There is a reference to the 63rd letter of St. Cyprian, including a quotation of the words "the priest truly acts in the place of Christ" (p.10)

By referencing the Fathers of the Church, the Council was emphasizing the continuity between its declarations and the priesthood and the sacraments as they have always been (if tacitly) understood. Today, the Catechism of the Catholic Church continues to teach that "the whole liturgical life of the Roman Catholic Church revolves around the Eucharistic sacrifice and the 
sacraments" (1113). The Catholic faithful view Catholic priests as agents of God in the delivery of the sacraments. Reading again from the Catechism:

The ordained ministry or ministerial priesthood is at the service of the baptismal priesthood [all members of the Catholic Church]. The ordained priesthood guarantees that it really is Christ who acts in the sacraments through the Holy Spirit for the Church... The ordained minister is the sacramental bond that ties the liturgical action to what the apostles said and did and, through them, to the words and actions of Christ, the source and foundation of the sacraments $(2000,1120)$.

The in persona Christi Capitis doctrine makes the Roman Catholic priesthood unique in the world of religious ministry because its authority does not depend upon subsequent personal merit. The only other religious organizations that feature similar doctrines or understandings are the Orthodox, Anglican, and Lutheran churches. While the faithful may likely prefer their ministers to serve as good moral examples, they can still receive the full value of the sacraments from sinful ones.

\section{$3 \quad$ Theoretical argument}

\subsection{Set up}

We analyze a simplified scenario with three actors: the Church, a priest, and a member of the faithful. ${ }^{8}$ The Church is the custodian of the doctrine. It specifies the rewards and punishments of different behaviors. These rewards and punishments are mostly spiritual, such as access to Heaven, Purgatory, or Hell. Importantly, the Church has ultimate authority on the nature and form of the sacraments, the only way through which the faithful may access the spiritual rewards. The priest acts as an intermediary between the Church and the faithful, particularly as it pertains to the supply of sacraments. He provides the faithful with other services as well, which we refer to simply as "religious services." The priest derives utility from consumption of sinful commodities, among others. As we discuss below, this sinful behavior may affect the faithful's willingness to pay for the Church's services and thus the value of the Church's brand. The member of faithful is someone who subscribes to the Church's teachings. As such, she has a derived demand for its sacraments and other religious services supplied by its agent, the priest.

The faithful's demand for the Church's sacraments and other religious services is a function of many variables. We focus on just two. First, the intensity of the faithful's demand is a function

\footnotetext{
${ }^{8}$ While members of the faithful are themselves part of the Church, we distinguish between the hierarchical institution, its agents, and its members in order to emphasize the distinct roles that each has in the overall Body of Christ.
} 
of her commitment to Church doctrine. Thus, changes in her faith in the authority of the Church will affect her willingness to pay for all that the Church has to offer. Second, the faithful will have lower demand for a sacrament if she suspects it to be of very low quality, or "invalid." This concern may arise because of the priest's sinful behavior, for instance.

In this scenario, the Church and the priest find themselves in a principal-agent relationship, the Church being the principal and the priest its agent. Specifically, the agency problem emerges from the fact that the Church has no way of interacting with the faithful to supply her directly with its services. ${ }^{9}$ Instead, the Church hires the priest to take on this task. More precisely, the Church-principal entrusts the priest-agent with a bundle of tasks: The production and supply of sacraments as well as of a variety of religious services such as spiritual guidance and prayer. ${ }^{10}$ The priest also agrees to behave according to the precepts of the Church. Thus, we can interpret the priest's restraint from sinful consumption as another task performed by him as an agent of the Church.

The impossibility for the Church to measure costlessly the priest's effort in the performance of all these tasks is what makes this principal-agent relationship consequential. In the absence of information costs, the Church could simply threaten to punish priestly shirking with a fine and/or termination. In such an equilibrium, the priest would opt not to shirk at all and the Church expects no negative consequence from entering the principal-agent relationship.

Alas, information being costly, asymmetry is likely to emerge between principal and agent, and the priest's decision to shirk will accrue losses to the Church. We restrict our analysis to just two channels through which they agent may harm the principal. First, if the member of the faithful becomes aware of some priestly misbehavior, she may lessen her estimate of the validity of the sacraments supplied by the priest. ${ }^{11}$ Which is to say, priestly misbehavior lowers the demand for one of the Church's main products. Second, the behavior of the priest may cause the member of the faithful to reduce the strength of her belief in the validity of the Church's teachings altogether. That is, the value of the Church's brand is negatively affected by priestly misbehavior. ${ }^{12}$ For instance, if the member of the faithful were to become aware of endemic scandalous behavior

\footnotetext{
${ }^{9}$ Alternatively, the Church can only do to so at exceedingly high cost, thus encouraging it to hire an agent for this purpose.

${ }^{10}$ Not to mention the wide array of non-religious services that the Church historically supplied to its members, from charity to schooling to property rights enforcement (Hull and Bold, 1989, 1995).

${ }^{11}$ In this context, sacraments have some of the properties of metacredence goods as formulated by Hull (1989) and extended by Ekelund and Tollison (2011).

${ }^{12}$ Our principal-agent problem could be reformulated in terms of the multi-tasking model developed by Holmstrom and Milgrom (1991). In order to effectively perform the tasks assigned to him by the Church, the priest is given access to assets - the Church's brand and reputation - to which the principal maintains ownership. Thus, priestly sinful behavior can be seen as a from of shirking in the performance of the task of preserving the value of the Church's reputation. We thank one anonymous reviewer for suggesting this alternative interpretation of our scenario.
} 
among the clergy, she may lose (some) faith in the Church as the ultimate authority on earth.

One final assumption pertains to the relative ability of Church and faithful to observe the priest's effort. Specifically, we assume that only the faithful may effectively monitor the behavior of the priest after his ordination, while the Church can more effectively screen the priest beforehand.

\subsection{Scenario 1: Equilibrium without in persona Christi Capitis}

Consider first the case in which no monitoring or screening of the priest takes place, and there is no in persona Christi Capitis doctrine. The Church hires the priest as its agent and entrusts him with the performance of the bundle of tasks described above, most importantly for our discussion, the supply and delivery of sacraments and the restraint from sinful consumption. We are interested in three outcome variables from this scenario: 1) The priest's level of sinful consumption; 2) the member of the faithful's monitoring of the priest; and 3) the Church's level of screening of the priest.

Let us consider sinful consumption first. Recall that the Church does no screening and the member of the faithful performs no monitoring. As long as the priest meets some threshold level of performance in the provision of the sacraments, he maintains his employment. This is a contractual provision that is relatively easy to enforce since the Church may simply count the number of baptisms, confirmations, marriages to establish their performance. Priestly sinful consumption will be such that private marginal benefit (marginal utility from sin) equals private marginal cost (the unit price of sin). However, the social marginal cost will be larger than the private one due to its effect on the faithful's willingness to pay for religious services and, thus, to the value of the Church's brand. With no screening nor monitoring, in the absence of the in persona Christi Capitis doctrine, incentives are such that the priest will indulge in higher-thansocially-optimal levels of sinful consumption. ${ }^{13}$

If faithful and Church recognize the possibility of priestly opportunism, they will find it in their interest to take action. On her part, the member of the faithful can do so by monitoring the priest priest, thus lowering the probability that the sacraments they consume will be revealed to be invalid ex-post. ${ }^{14}$ However, this monitoring is unlikely to prevent all sinful behavior by the

\footnotetext{
${ }^{13}$ While not the focus of our inquiry, competition from other religious leaders both without and within the Church (i.e., other Catholic parishes and priests) may also contribute to disciplining the behavior of priests. For instance, Gill (2008) shows that when the Catholic Church faced fiercer competition from Protestants in Latin America during the late 20th century, Catholic priests and bishops began to improve their behavior.

${ }^{14} \mathrm{An}$ alternative for the member of the faithful would be to make a side payment to the priest to discourage him from sinful consumption. However, it is unlikely this solution would be feasible in our context. For one, such a promise would encourage individuals with stronger preferences for sinful consumption to enter the priesthood since they would receive higher compensation for abstaining from it. Another reason is that this strategy may be self-defeating. If the priest requires compensation to abstain from sinful consumption, this would signal the faithful something about his moral character and, thus, lower their willingness to pay for his services. Finally,
} 
priest. This is for two reasons. First, monitoring is costly, so it will be less than complete in equilibrium. Second, monitoring by the faithful generates benefits to the Church for which she does not receive compensation, resulting in "too little" monitoring from society's perspective.

A similar argument can be made for Church screening. Assume that, by spending more resources on screening candidates to the priesthood, the Church may be able to select a priest with weak preferences for sinful behavior. Screening being costly, the Church will always choose less than complete screening in equilibrium. This will result in some priests with strong preferences for sinful behavior making their way into the priesthood. Another element suggesting that the Church will fall short of perfect screening is that it will be tempted to free ride on the faithful's monitoring of its agent. Overall, in the absence of the in persona Christi Capitis doctrine, we should observe some combination of screening and monitoring, both imperfect and incomplete, and some sinful behavior by the priest.

In order to meet the individual rationality constraint, the Church must offer the priest a contract such that the latter is at least as well-off at his optimum with Church screening and faithful monitoring as he would be in his best alternative employment. Let $w_{a}$ be the wage associated with this employment while $w_{b}$ is the wage he receives as agent of the Church. The higher $w_{b}$ relative to $w_{a}$, the less monitoring by the faithful would be necessary to reduce sinful consumption since $w_{a}$ acts as an efficiency wage. The reverse will also be true. The lower $w_{b}$ relative to $w_{a}$, the more monitoring will be necessary to reduce priestly sinful consumption. Due to the crowding out effect of monitoring on screening, a fall in $w_{b}$ relative to $w_{a}$ would seem to reduce the incentives to the Church of screening candidates to the priesthood.

The direct effect on screening of a change in $w_{b}$ relative to $w_{a}$ is likely to have the opposite effect. A higher $w_{a}$ would discourage people who are not strongly motivated to join the priesthood from entering that line of work. This should lower the equilibrium level of screening by the Church. Thus, the overall outcome will depend on the relative magnitude of the incentive effect (outside wages affect the efficacy of monitoring) and the selection effect (outside wages affect the willingness of individuals to enter the priesthood in the first place).

\subsection{Scenario 2: Equilibrium with in persona Christi Capitis}

Consider now the alternative scenario in which the Church incorporates the in persona Christi Capitis doctrine. This states that the value of the sacraments is independent of the personal morality of the priest. Besides this doctrinal change, the relationship between the three actors remains unaltered. The Church hires a priest to act as its agent in supplying the faithful with a

the priest may be unable to perfectly commit to his promise to abstain from sinful consumption in exchange for payment. Even though the latter may work as an efficiency wage to reduce his sinning, the member of the faithful will have to perform at least some monitoring to ensure contractual compliance. 
bundle of sacraments and other religious services. Key to this scenario is the fact that the member of the faithful need now not worry about priestly sinful consumption when it comes to the validity of the sacraments. The latter are valid by default, regardless of the priest's behavior or moral status. Yet, this is not to say that sinful behavior by the priest has no consequences. If the priest is revealed to be morally corrupt, this may still cause the member of the faithful to lower her belief in the teachings of the Church and, thus, her willingness to pay for all its services. ${ }^{15}$

Given the possibility of priestly behavior affecting the value of the Church's brand, the principal-agent relationship between the two remains consequential once the in persona Christi Capitis doctrine is introduced. However, we expect the doctrinal change to affect our three variables of interest (priestly sinful consumption, faithful monitoring, and Church screening). As we did in the analysis of the first scenario, let us consider first the level of sinful consumption with no monitoring or screening. Since the doctrinal change does not affect the private benefits and costs of of sinful consumption, the result should be the same: The priest selects his optimum by equating marginal private benefit and marginal private cost.

The adoption of the doctrine does however affect the incentives of the faithful. In the first scenario, the member of the faithful invested in monitoring the priest in order to reduce the probability that sacraments would be revealed to have been invalid ex-post. No such worry exists in our second scenario. Thus, the incentive to monitor the priest is reduced. With less monitoring, the level of priestly misbehavior will be higher in this scenario than it was in the first. However, while the priest's behavior now does not directly affect the faithful's demand for sacraments, it still affects her demand for the Church's services as a whole. Thus, the Church may respond to the lower levels of monitoring by ramping up screening in order to mitigate the increase in priestly sinful consumption and avoid a reduction in the value of its brand.

As in the first scenario, the Church must offer the priest a contract such that the latter at least as well-off at his optimum in the in persona Christi Capitis equilibrium as he would be in his best alternative employment. As above, let $w_{a}$ be the wage associated with this employment while $w_{b}$ is the wage he receives as agent of the Church. Since there is no monitoring by the faithful in this equilibrium, this does not affect (nor is it affected) by changes in $w_{a}$ relative to $w_{b}$. Thus, in our second scenario, changes in relative wages do not affect the priest's incentives for sinful consumption.

The magnitude of $w_{a}$ relative to $w_{b}$ will likely still have an effect on the Church's decision of how much screening to perform. The higher $w_{a}$ relative to $w_{b}$, the more motivated the average candidate to the priesthood to join the Holy Orders. This in turn lowers the Church's incentive

${ }^{15}$ There is strong evidence to suggest that scandalous behavior by priests has had a large negative effect on both affiliation with the Catholic Church and on donations by parishioners (Hungerman, 2013). 
to screen its candidates. ${ }^{16}$ A higher external wage would then translate to both less screening and less sinful consumption by the priest since more committed people join the priesthood in the first place. $^{17}$

\subsection{Implications}

This discussion identifies one key implication of the introduction of a doctrine that seemingly increases the priest's incentive to misbehave: Moving to an equilibrium with in persona Christi Capitis is accompanied by an increase in screening efforts by the Church to compensate for the fall in monitoring efforts by the faithful. However, doctrinal choices by the Church are not entirely exogenous: The adoption of this doctrine may be seen as a credible signal by the Church that it will take onto itself the burden of ensuring the quality of its priests and sacraments by screening more intensely candidates to the priesthood.

The framework also aids us in identifying potential factors behind the development and adoption of this doctrine:

1. An increase in the cost of monitoring by the faithful

2. An increase in the cost of priestly misbehavior to the Church

3. A fall in the the cost of screening by the Church

In the following section, we show that all major developments of the in persona Christi Capitis doctrine coincided with historical episodes that can be interpreted as some combination of changes in (1) through (3). We also show that among contemporary Christian denominations, adherence to the view that religious ministers act as agents in the delivery of God's grace to the faithful is correlated with the adoption of doctrines akin to the in persona Christi Capitis as well as a higher degree of monitoring of candidates to the clergy.

\footnotetext{
${ }^{16}$ Reversely, the lower $w_{a}$ relative to $w_{b}$, the less motivated the average candidate to the priesthood to join the Holy Orders.

${ }^{17}$ However, consider the case of an individual with very strong preferences for a very specific kind of sinful consumption that has a lower marginal cost to members of the priesthood than "civilians." The combination of higher $w_{a}$ relative to $w_{b}$ and the introduction of the in persona Christi Capitis doctrine may make it more likely for this person to become a priest. On the one hand, less monitoring means more freedom to indulge in his favorite kind of sinful consumption, which in turn motivates him to join the priesthood. On the other, a higher $w_{a}$ means less screening, which increases his chances of being hired as an agent of the Church. The relevance to recent scandals in the Catholic Church in the United States is evident.
} 


\section{Evidence}

To test the validity of our theory, we show that the introduction of the in persona Christi Capitis doctrine and its development did indeed correspond to increases in the Roman Catholic Church's efforts to screen candidates to the priesthood (i.e., seminarians). Specifically, we follow our theoretical discussion above and track three underlying parameters that would predict such changes:

1. The cost of monitoring by the faithful

2. The cost to the Church of morally hazardous behavior by the priest

3. The cost of screening by the Church

We show that shifts in these parameters precede the key points of development of the in persona Christi Capitis doctrine: first, with the Church Fathers, then, at the Council of Trent, and finally, during the Counter-Reformation. ${ }^{18}$ We connect our analysis with more recent studies of the various Christian seminaries and their requirements for seminarians and conclude by discussing some implications of our theory for the most recent sex abuse scandal in the Roman Catholic Church in the United States.

\subsection{Evidence from the Roman Catholic Church}

The earliest formulation of the in persona Christi Capitis doctrine dates back to the early fifth century AD, when a North African Bishop, Augustine of Hippo, employed it in his attack against the Donatist heresy. As the Roman Catholic Church began explicitly embracing this theological position, we expect it to also take action to increase its screening of candidates to the priesthood. And so it did. In the decades following the victory over Donatism, the Roman Catholic Church encouraged its bishops throughout Christendom to adopt a new institution: the monasterium clericorum, forerunner of today's seminary. Coincidentally, this institution was the brainchild of the very Augustine of Hippo who was responsible for formalizing the early Church's position on the nature of the sacraments and their relation to the priesthood. By the first half of the sixth century, with the Councils of Vaison (529 AD) and Toledo (531), the Church began requiring parishes to institute seminaries for the training and instruction of young clerics, under the direct supervision of the local bishop (Vieban, 1912). These "cathedral schools" and monasteries spread

\footnotetext{
${ }^{18}$ The Congregation for the Clergy explains what development means with regard to doctrines concerning the Catholic priesthood: "This deepening of doctrine has carried with it a profound consequence in the reform of the ecclesiastical institution, but it is significant to show that always, by means of diverse formulations of human laws, one rediscovers the institutions of the early Church, of the Church of all time" ("Priests in the Early Church and in Vatican II").
} 
rapidly throughout the early Middle Ages and grew in prominence within the Church and medieval society as well.

The parallel success of the in persona Christi Capitis doctrine and the institution of the seminary coincided with significant structural changes in the social, political, and economic landscapes of Early Medieval Europe. The most consequential among these was the normalization of the Church's relations with the Roman Empire and the end of the prosecution of Christians in its territories. Practicing one's Christian faith in public and private became less costly following this development as the number of martyrs dropped substantially from the fifth to the sixth century. One unintended consequence of the end of Christian persecution was that the threat of martyrdom no longer served as selection mechanism for the clergy. Consider the account of the martyrdom of Justin and his companions:

The Prefect Rusticus says: Approach and sacrifice, all of you, to the gods.

Justin says: No one in his right mind gives up piety for impiety.

The Prefect Rusticus says: If you do not obey, you will be tortured without mercy.

Justin replies: That is our desire, to be tortured for Our Lord, Jesus Christ, and so to be saved, for that will give us salvation and firm confidence at the more terrible universal tribunal of Our Lord and Saviour.

And all the martyrs said: Do as you wish; for we are Christians, and we do not sacrifice to idols.

The Prefect Rusticus read the sentence: Those who do not wish to sacrifice to the gods and to obey the emperor will be scourged and beheaded according to the laws.

The holy martyrs glorifying God betook themselves to the customary place, where they were beheaded and consummated their martyrdom confessing their Saviour (Lebreton, 1910).

Few people with only a superficial commitment to the Christian faith would be willing to risk this fate. Once persecution ceased in $312 \mathrm{AD}$, priests and bishops became public figures and could move more freely in the territories of the Empire. This allowed Christianity to spread far and wide and brought a rapid increase in the number of the faithful. ${ }^{19}$ These growing numbers also meant that priests were desperately needed - a need that Augustine, the Bishop of Hippo, also would have been aware of when arguing in favor of absolution for the apostates and the sacramental guarantee of in persona Christi Capitis. The end of the selection effect provided by the threat of martyrdom, combined with the rising size of parishes, and the distance of many such parishes from Rome contributed to an increase in the cost of monitoring priestly behavior.

\footnotetext{
${ }^{19}$ See Stark (2007b) for a quantitative, historical analysis of the urban growth of Christianity during this period.
} 
Ekelund and Tollison (2011) characterize the behavior of Rome during this time as that of a firm attempting to establish itself as the market's monopolist supplier. They note that the process of monopolization required it to vertically integrate the production of its output in order to increase the degree of its homogeneity. Vertical integration and output homogeneity would avoid non-price competition between different parishes within the church, which would have driven its monopoly rents to zero. Just as "unorthodox doctrine taught at the local levels would damage the integrity of the [Church's] product" so too would sinful behavior by the priest in the now vertically-integrated Church be more costly (Ekelund and Tollison, 2011). In other words, as the Roman Catholic Church worked to make its religious service homogeneous and universal, the the cost of morally hazardous behavior on the side of its agents went up, providing it with a stronger incentive to screen candidates to the priesthood. Consistent with our framework, the events that defined the history of the Early Medieval Church - the increase in the cost of monitoring priestly behavior and the negative effect of this behavior to the Church's bottom line - encouraged the formation of a doctrine like in persona Christi Capitis and increase in the amount of screening of candidates wishing to enter the priesthood.

The second key episode in the development of the in persona Christi Capitis doctrine was the Protestant Reformation of the sixteenth century. Some Protestant challengers of Rome pointed to the corruption in the body of the Church as evidence of the superiority of their own theological positions on priesthood, hierarchy, and sacraments. In response to these challenges, the Roman Catholic Church further clarified its position on the nature of the sacraments and the role of the priesthood as intermediaries between God and the faithful.

This too coincided with a drastic reform of the the training of its clergy. The Council of Trent (1546 AD), the same that had reaffirmed the Church's position on the role of the priest in the production and delivery of the sacraments, also set out seminary guidelines. According to these reforms:

1. Each diocese was required to support and train young men for the priesthood.

2. Boys admitted to the seminary may be no younger than 12 .

3. All seminarians had to be taught to read and write.

While they applied to all universities and seminaries in the Catholic Church, the enforcement of these reforms varied depending of the local circumstances. The large Roman Seminary was established in 1564, and others spread throughout Italian dioceses rapidly. Persecution in England and Ireland prevented the foundation of seminaries, but before the French Revolution, priests for the English mission were trained at the English College of Douai. As universities were subjected to increasing control of the secular authorities, the Catholic Church was eventually forced to start 
new, independent seminaries throughout the continent. These changes had a lasting effect on the institutional structure of the Church. So much so, that Cardinal Pallavicini, a leading historian of the Council, referred to the restructuring of the institution of the seminary as "the most important reform enacted by the council" (Vieban, 1912).

The Roman Catholic Church has maintained a consistent approach to the formation of its clergy since. Today, before an unmarried, ${ }^{20}$ baptized Catholic man can be ordained a priest, he must complete a selective and demanding process that encompasses the following four "formations:"

1. Human formation: Where the diet, exercise, sleeping habits, hygiene, social skills, fraternity, manners, work ethic, humor, and time management skills of the seminarian are examined.

2. Spiritual formation: Where the seminarian frequently consults with his Spiritual Director for guidance on holiness, habits of prayer, content for prayer, vices he struggles with, virtues he needs to grow in, his practice of the sacraments and ability to do holy hours, spiritual reading, etc. Observable behaviors that are taken into account here include his attendance at Mass and public prayer, his more obvious and natural virtues, external habits of prayer, frequency of holy hours, tardiness to house liturgies, attentiveness at morning and evening prayer.

3. Intellectual formation: Every seminarian must complete four years of College Seminary (studying philosophy) then four years of Major Seminary (studying theology). If he already has a college degree in a related discipline, this plan of study may be reduced to six years.

4. Pastoral formation: Every seminarian has certain apostolates, which are opportunities to volunteer and serve the people. They go to parishes to visit the sick, take communion to the elderly, and teach religious education classes. They are also trained in pastoral counseling, management, homiletics (i.e., the art of writing and preaching sermons), marriage preparation, and counseling.

In order to complete this process successfully, the candidate to the priesthood must invest significant amounts of time and effort to his formation, as well as make human capital and social capital investments that are specific to religious life. This is exemplified by the daily routine expected of a Catholic seminarian:

[T]he student rises at 5 or 5.30 a.m., makes his meditation for a half-hour, hears Mass, and usually receives Communion. Breakfast is about two hours after rising. In the

\footnotetext{
${ }^{20}$ Exception to celibacy in the Roman Catholic Church exist for churchmen from selected non-Roman rites especially among the Eastern European rites - and among Anglican churches in communion with Rome through the institution of the Personal Ordinariate.
} 
forenoon there are two classes of one hour each, while two hours also are devoted to private study. After dinner there is about an hour of recreation. In the afternoon four hours are divided between class and study, and as a rule another hour of study follows supper. A visit to the Blessed Sacrament, the recitation of the Rosary, and spiritual reading take place in the afternoon or evening; and the day closes with night prayer. Thus the student has devoted about three hours to exercises of piety and nine hours to work. After six years of this mental and moral training in retirement from the world, and in the society of fellow students animated by the same purpose and striving after the same ideals, he is deemed worthy of receiving the honour and capable of bearing the burden of the priesthood (Vieban, 1912). ${ }^{21}$

\subsection{Evidence from other Christian denominations}

We expect other Christian denominations that have embraced similar doctrines regarding the sacraments to have adopted comparable strategies to mitigate the risk of opportunism on the part of their ministers. One such religious organization is the Orthodox Church. While theologically the Orthodox Church tends to emphasize the essential mysteriousness of theological truths, it overlaps nearly entirely with Roman Catholicism when it comes to doctrinal understanding. Indeed, the Catholic Churches recognizes that its Orthodox counterpart has maintained apostolic succession and thus sees its sacraments as valid. ${ }^{22}$ Accordingly, the Orthodox Church recognizes all seven sacraments identified by the Roman Catholic Church. It also endorses the doctrine of in persona Christi Capitis:

The one sacrament within the Church which guarantees the identity and continuity of the Church in all times and places is the sacrament of priesthood, the "holy orders," as they are called. The priesthood exists within the Church as the sign of the certain presence in the community of Christ Himself. Christ is not absent from the Church. He is present as its head and is manifested in the Body through the ministry of the priesthood (The Orthodox Church in America, 2020).

While priestly formation in the Orthodox Church does not exclude married men from the clergy, it shares with the Catholic Church a lengthier and more formal seminary formation period than

${ }^{21}$ In the United States, where unmarried young men may face a relatively high opportunity cost of entering the priesthood, the average retention rate in theologate (post-college) seminaries was $74 \%$ over the last few years (Kramarek and Gautier, 2019). Almost one in four men who enter the seminary do not make it through and will not become priests.

${ }^{22}$ The Orthodox Catholic Church broke with the Roman Catholic Church in the Great Schism of 1054, though it retained the hierarchical structure and tradition of the original unified Catholic Church. 
any other Christian denomination. Seminarians must attend a four-year program at one of few Orthodox seminaries before they are ordained by a bishop.

Lutheranism, though independent of the Roman Catholic Church since the Protestant Reformation, also holds that the efficacy of the sacrament is not determined by the holiness of the minister. Articles 7 and 8 of "Apology of the Augsburg Confession" (1531) by reformer Philipp Melanchthon, state:

Nor does this detract from the efficacy of the sacraments when they are distributed by unworthy [ministers] because they represent the person of Christ on account of the call of the Church and don't represent their own persons (no. 28).

However, Lutherans recognize just two of the seven Roman Catholic sacraments - Holy Baptism and Holy Communion. Thus, a smaller share of the religious services provided by the Lutheran Church relies on the value of the sacraments. For this reason, we should expect the rigor of seminary screening to be relatively less than that of the Roman Catholic seminarian, for whom the sacraments are a lifelong and primary function of religious ministry.

The Anglican Church also provides a helpful counterfactual, not only because it originally split from the Roman Catholic Church over a disagreement concerning a sacrament (Matrimony), but because there is increasing discussion regarding the celebration of sacraments within its tradition. Just like Lutherans, the Anglican Church traditionally recognizes only two sacraments: Baptism and Communion. ${ }^{23}$ Like the Roman Catholic Church, the Anglican Church is hierarchically organized with bishops and priests and claims apostolic succession. ${ }^{24}$ However, the de jure and the de facto diverge more widely in the Anglican Church, perhaps because the Anglican church does not claim to be the only true church. Certain Anglican congregations emphasize their Catholic heritage, doctrine, and traditions (and are thus sometimes dubbed Anglo-Catholics). Other Anglican congregations have adopted reformed or charismatic features akin to those of mainstream Evangelical Christianity in the United States. ${ }^{25}$

\footnotetext{
${ }^{23}$ As for the remaining Catholic sacraments:"Those five commonly called Sacraments, that is to say, Confirmation, Penance, Orders, Matrimony, and Extreme Unction, are not to be counted for Sacraments of the Gospel, being such as have grown partly of the corrupt following of the Apostles, partly are states of life allowed in the Scriptures, but yet have not like nature of Sacraments with Baptism, and the Lord's Supper, for that they have not any visible sign or ceremony ordained of God" (Convocation, 1562, XXV).

${ }^{24}$ Apostolic succession refers to the line of bishops tracing back to the apostles. Various Christian churches the Catholic, Orthodox, and Anglican Churches amongst them - claim this feature as a core support for their authority.

${ }^{25}$ This divergence has a geographical pattern, with the Anglican Church in England moving toward a less rigorous interpretation of doctrine while the African Anglican Church retains a commitment to stricter theology. Because there is greater competition in Africa amongst not only Christian but pagan religions, the relatively stronger doctrinal positions of the Anglican Church in Africa may serve to enhance the credibility of their ministers. We thank an anonymous reviewer for drawing our attention to this fact.
} 
Since it recognizes two sacraments, we expect the Anglican Church to follow the Catholics, Orthodox, and Lutherans in adopting a doctrinal stance along the lines of the in persona Christi Capitis and an organization compatible with the related incentives. The historical record validates this expectation. In the 39 Articles of Religion of 1562, the foundational document of the Anglican Communion, one reads the following:

Although in the visible Church the evil be ever mingled with the good, and sometimes the evil have chief authority in the Ministration of the Word and Sacraments, yet forasmuch as they do not the same in their own name, but in Christ's, and do minister by his commission and authority, we may use their Ministry, both in hearing the Word of God, and in receiving the Sacraments. Neither is the effect of Christ's ordinance taken away by their wickedness, nor the grace of God's gifts diminished from such as by faith, and rightly, do receive the Sacraments ministered unto them; which be effectual, because of Christ's institution and promise, although they be ministered by evil men (Convocation, 1562, XXV)

Due to the internal division between Anglo-Catholics and "low church" congregations, the Anglican Church does not supply uniform religious and spiritual services. For instance, the frequency of the celebration of Holy Communion varies in popularity and practice between Anglican congregations.

The Anglican Church implements some screening in the selection of ministers. Predictably, these efforts are generally not as extreme as those of the Roman Catholic Church. For instance, married men and women are not excluded from ministry. Ministerial formation is less rigid than in Catholicism and more strongly tied to one's local congregation: ${ }^{26}$

[The] process begins with a meeting with your Rector. You will discuss your sense of calling, and meet regularly to discern together before any decision is made about a formal discernment process...You will then meet with a group of lay people to talk, to pray, and to see if they can confirm your call to ordained ministry. Why do we do this? From the early days of the Church, laity affirmed the call to ordained ministry, as did the clergy, thus preventing the clergy orders from becoming a self-selected body... Therefore, the role of lay people in your discernment process is extremely important and sacred" Goebel (2015).

Strictness of selection varies from Anglican diocese to diocese, but the minimum requirements are shared by most. ${ }^{27}$ These include:

\footnotetext{
${ }^{26}$ Recently, the Anglican church has been debating (and certain diocese have been open to) the ordination of individuals in homosexual relationships.

${ }^{27}$ While we do not have sufficient evidence to test this, our theory would predict that the local Anglican seminary
} 
1. A recommendation of ordination from a regional conference and the bishop's approval

2. Subjection the bishop's guidance on specific training, for example:

(a) A three year program at an accredited seminary

(b) Local night classes and individual mentorship

Figure 1 displays the minimum formal seminary training required for candidates to religious ministry across the largest Christian denominations in the United States. The minimum number of formal seminary years required - a proxy for the intensity of the screen - is tracks pretty closely a denomination's stance on the nature and number of sacraments.

[FIGURE 1 HERE]

Consistent with our framework, denominations that recognize the validity of at least two sacraments and envision a role for religious ministers in their production and supply to the faithful are stricter than ones who do not. The six strictest denominations according to our measure all fall within the former category. The five denominations who are the most informal, on the other hand, all reject the in persona Christi Capitis doctrine and make no room for the clergy in the delivery of God's grace to the faithful. The average denomination that recognizes the validity of at least two sacraments demands just over 4 years of seminary training from the candidates to religious ministry. This is two and a half times the figure (1.7 years) for denominations that reject the validity of any sacrament.

Another way to estimate the intensity of a seminary screen is by the specific investments in human capital required of the trainee. One such investment in specific human capital is the sacrifice of time to prayer. Table 2 summarizes evidence from Finke and Dougherty (2002) on the number of hours that the training ministers are required to spend praying every day. While most denominations feature a tradeoff between coursework and prayer time, the authors note how "Catholic clergy seem to defy this trend of increasing training and declining prayer" (p. 112). Along with a high course load, Catholic seminaries also require nearly twice as many hours of prayer each week from its seminarians.

\section{[TABLE 2 HERE]}

Moreover, Finke and Dougherty (2002) argues that seminary training can be highly costly to trainees since it removes him from a broader social network and supplies him with specific connections to the church hierarchy instead.

requirements be positively correlated with the strength of their position on the sacraments. For instance, a comparison of the Scottish Episcopal Church (less emphasis on sacraments) and the Episcopal Church of the U.S. (more emphasis on sacraments) would be interesting with more information about their detailed seminary requirements. 


\subsection{Celibacy requirements}

One feature of the Catholic priesthood that is unique in mainstream Christianity is the requirement of lifelong celibacy. ${ }^{28}$ Although celibacy is a discipline of the Catholic Church, not a doctrine (and thus potentially an object of reform), this practice has been continually tested and confirmed by the Church throughout history. In this subsection, we briefly explore how priestly celibacy fits within our argument.

The issue of celibacy has been dealt with in economic scholarship before. Hull and Bold (1989) argues that priestly celibacy can be understood as a signal of priestly religious sincerity and commitment to their belief in the Church's doctrine to potential consumers. He further hypothesizes that celibacy may have emerged as a way to "encourages honesty by priests since celibate priests cannot pass wealth to heirs" (Hull and Bold, 1989, p. 11). Similarly, Ekelund et al. (1996, 2008); Ekelund and Tollison (2011) suggest that the Church's emphasis on priestly celibacy following the Council of Trent may have served to change public perception of the priesthood as a corrupt bunch. Local priests were to give up married life to assure believers that they themselves believed in the quality of the Church's product.

Our framework points in the direction of an alternative, though possibly complementary, interpretation. Celibacy may have been adopted by the Church as a way to screen out candidates to the priesthood with a low commitment to its teachings. Moreover, our framework suggests that the celibacy requirements make more sense in the context of a hierarchically organized Church in which the Church itself screens candidates to the ministry rather than relying on monitoring by the faithful. ${ }^{29}$ Evidence from the history of the Catholic Church and other denominations provides some support to our interpretation. Most importantly, we find that the development of the in personal Christi Capitis doctrine matches the evolution of the Church's position on priestly celibacy.

An early statement of the Church's position on celibacy is well encapsulated in Pope Leo the Great's missive to Bishop Rusticus of Narbonne (c. 459):

The law of continence is the same for the ministers of the altar, for the bishops and for the priests; when they were (still) lay people or lectors, they could freely take a wife and beget children. But once they have reached the ranks mentioned above, what had been permitted is no longer so (Schaff and Wace, 1895).

\footnotetext{
${ }^{28}$ Even within the Catholic Church, there are exceptions to the celibacy requirement. For instance, deacons of mature age are allowed to marry. The most striking exception however is the one that was carved out for married ministers of other Christian denominations that ask to reunite with the Catholic Church following a precedent set by Pope Pius XII.

${ }^{29}$ In the context of our theoretical framework, the Church has a larger incentive to require costly signaling by candidates to the priesthood after it adopts the in persona Christi Capitis doctrine and must expand screening efforts to compensate for the fall in monitoring by the faithful.
} 
In the early Church, celibacy was not a requirement for priests or even bishops, but came to be recognized as the preferred lifestyle for priests during the ascent of monasticism and the Gregorian Reform (Pope Gregory I himself having been a monk) (Frazee, 1988; Cholij, 1993). During this time, it was not unusual for Catholic priests to have wives and families who, while perhaps serving to moderate their behavior, also had claim to their resources and time. ${ }^{30}$ However, already by the third and fourth centuries - while debates over the in persona Christi Capitis doctrine were also taking place - some in the Church started supporting the view that celibacy had required of priests. During this time there was a change in the role of the priest among the ranks of ever more numerous Christians and within the hierarchy of a Church that was growing more public, official, and subsequently, complex (Frazee, 1988). Traditional arguments in favor of celibacy - such as the commitment of one's life to serve only Christ and His flock - began to be strengthened by pragmatic concerns:

This discussion on ecclesiastical property introduces the two problems which worried conscientious Christians of the day: the upper clergy were too involved in the service of the state, and the lower clergy were too powerless in the feudal system. Church property which was set aside for the use of entire Christian community was in danger of falling completely into private hands if a married clergy became accepted (Frazee, 1988, p. 119).

This danger was exacerbated by priestly misbehavior, such as simony (the buying or selling of ecclesiastical privileges) and sexual relations outside of marriage (which may bring forth illegitimate children). ${ }^{31}$ The charge against the married priesthood took place in this historical context. Concerned with the growing corruption among the clergy ${ }^{32}$ the Church convened its Second Lateran Council (1139). The Council took a strong stance against the internal opposition to priestly celibacy, leading to the adoption of Canons 6 and 7 which formalized the requirement that all priests make a vow of celibacy. However, the Second Lateran Council did not end corruption in the Church nor did it end the debate over the issue of priestly celibacy. Opposition to mandatory celibacy was a key element of Luther's theological and political challenge to the Church (Abbott, 2000). Luther, Calvin, and other reformers saw celibacy as an unnecessary and indeed hurtful burden on religious ministers. ${ }^{33}$. The Roman Catholic Church responded by "[reasserting] clerical

\footnotetext{
${ }^{30}$ Interestingly, Becker (2011) argues that the disproportionate representation of Protestants over Catholics in the Scientific Revolution amongst German scientists can be attributed to the higher human capital accumulation and social networks of the children of clergy.

${ }^{31}$ See Rodney Stark's discussion of this period of Church history (Stark, 2016).

${ }^{32}$ The Council was convoked to address an array of items mostly related to the negative consequences of the schism of 1130 (Herbermann, 1913).

${ }^{33}$ Abbott (2000) quotes Luther as arguing that priests should enter marriage in order to avoid the "reprehensible" consequences of celibacy: "constant burning [and] unclean pollutions."
} 
celibacy ... as a permanent marker of the division within Christendom, and defined a discipline for the Catholic church which has continued to the present day" (Parish, 2016, p. 2). This stance relied, at least in part, on the Catholic Church's theological interpretation of the role of the priest as serving in persona Christi, but also on the practical consideration that this role "[requires] total dedication to God, in the administration of the sacraments, in preaching, an in a life of perpetual prayer" (Parish, 2016, p. 6, 192).

The latest Council of the Catholic Church - the Second Vatican Council - reaffirmed Rome's position on the celibacy if the clergy. However, it noted that celibacy was "not required by the nature of the priesthood" even as though it recognized the "fittingness" of a celibate priesthood (Levada, 2011). This, alongside other reforms, was interpreted by many within the hierarchy and the faithful as a general fall in the sacrifices demanded of the Catholic clergy (and, to some extent, of laypeople). A few decades later, Pope John Paul II worked to reverse these trends in favor of a greater emphasis on the unique role and responsibilities of the priest and the function of priestly celibacy (Pablo II, 1986). More recently, Pope Francis restated the Church's commitment to the discipline of celibacy in response to demands that it relax these requirements for those clergy serving in "remote regions" like the Amazon. In one proclamation, he explicitly links his opposition to the proposed reform with the in persona Christi Capitis doctrine:

The priest is a sign of that head and wellspring of grace above all when he celebrates the Eucharist, the source and summit of the entire Christian life. That is his great power, a power that can only be received in the sacrament of Holy Orders. For this reason, only the priest can say: "This is my body." There are other words too, that he alone can speak: "I absolve you from your sins." Because sacramental forgiveness is at the service of a worthy celebration of the Eucharist. These two sacraments lie at the heart of the priestâs exclusive identity (Francis, 2020).

Contemporary cross-sectional evidence is also consistent with the interpretation of celibacy as a costly signal emerging in conjunction with the in persona Christi Capitis doctrine. The only other mainstream Christian denomination that emphasize priestly celibacy besides the Catholic Church is the Orthodox Church. While the latter does not require that its ministers be celibate, celibacy is encouraged and tradition demands that Orthodox bishops be celibate. Indeed, traditionally, if a bishop had been married at the moment of his election, his wife was to retire to a convent.

The adoption of the in persona Christ Capitis doctrine seems to coincide with an emphasis on celibacy for one's ministers. Rejection of this doctrine, coincides with the opposite attitude towards celibacy. Protestant traditions go as far as to encourage pastors especially to marry. This sentiment goes back to Reformation, when Martin Luther denounced priestly celibacy as a 
universal policy, arguing that it kept clergy and laypeople apart. ${ }^{34}$

\section{Conclusion}

We provide a theoretical analysis of some agency problems in the production and delivery of sacraments in hierarchically organized religious groups. Specifically, we argue that a doctrine on the nature of sacraments as metacredence goods whose value does not rely on the agent exposes a Church to priestly moral hazard. We show that, to be effective, this doctrinal development must be accompanied by an investment in the screening of candidates who work as sacramental agents for the Church.

To corroborate our argument, we draw evidence from the history of the Roman Catholic Church specifically with regard to the development of the in persona Christi Capitis doctrine. We show that the introduction and development of this doctrine coincided with the Roman Catholic Church's adoption of institutional changes that increased the screening of future priests, for instance, via the creation of formal seminaries. Our analysis emphasizes three parameters that shifted and made screening by the Roman Church the optimal solution to the threat of moral hazard: 1) an increase in the cost of monitoring for the faithful due to priest mobility and parish size, 2) an increase in the cost of morally hazardous behavior to the Church as its reputation became more valuable, and 3) a reduction in the cost of screening by the Church with the rise of universities and literacy. Finally, we present evidence that the intensity of screening across Christian denominations is correlated with these groups' theological position on sacramental matters. Denominations such as the Orthodox, Lutheran, and Anglican churches that are close to the Roman Catholic Church in their theological position with respect to the sacraments screen candidates to the religious ministry more intensely than ones who do not.

Our argument may shed light on some aspects of recent scandals concerning Catholic priests that repeatedly broke headlines in the United States over the last several decades. ${ }^{35}$ Our theory mainly points to a failure of the Church in screening candidates to the priesthood. Indeed, according to the reports that continue to be released to this day, those clergy members in charge of educating or spending time with young seminarians were themselves full or partial participants in the same scandalous behavior (Boorstein, 2019). Given that the faithful may expect this function

\footnotetext{
${ }^{34}$ Hull and Bold (1989) argues that by not requiring such costly sacrifices, Protestant churches were able to compete with the Catholic church in attracting candidates to their ministry.

${ }^{35}$ The sexual abuse scandals reach back before 1984, when Bishop J. Douglas Deshotel wrote a pastoral letter on the topic following news that a Louisiana priest had molested over 30 children. Attention increased when the John Jay Report (2004), commissioned by the U.S. bishops, showed that only about $10 \%$ of the eventually reported incidents had been reported to dioceses by 1985. In 2002, stories in the Boston Globe brought many new allegations from the past to the forefront.
} 
from the Church, this failure may not have been immediately compensated by for by an increase in monitoring by local parishioners. ${ }^{36}$ The American Catholic Church has paid and still pays a high price for its failure. Within our framework, the damage done by these sinful acts has the effect of reducing the perceived "quality" of the entirety of the Church's brand. According to recent estimates (Esparza, 2020), dioceses hit by a scandal experienced a 13.2\% decline in infant baptisms (averaging 1400 fewer baptisms based on the pre-scandal mean), a 17.1\% decrease in diocesan high school enrollment while nonreligious private schools experience an increase in high school enrollment, and an increase of $3.9 \%$ and $2.8 \%$ in the incidence of high mortality from accidental overdoses and suicides (respectively) for middle aged men. These figure exemplify the potential damage to the Church's reputation posed by its own doctrine when it neglects to accompany it with rigorous screening.

Although a clear example, the Catholic Church is not the only organization that balances quality guarantees with the requirement of costly sacrifices. Extensions of our research may be found in analyzing political parties, the legal and medical professions, and even universities. Still, the survival of the Church throughout the ages is itself evidence of its having at times managed these institutional incentives effectively (Gill, 2020).

\footnotetext{
${ }^{36}$ However, in the wake of the crises, several lay groups from within the Church have begun to mobilize in response. For a thorough introduction to this crisis and the response of the Catholic Church, see The Catholic Project at Catholic University, and accompanying documentary-style podcast Crisis: Clergy Abuse in the Catholic Church.. Warner (2019) also draws parallels between the scandals of the Church and those of the U.S. military. Since both are hierarchical, sacred or quasi-sacred, and require great sacrifices of members, victims of crimes in these organizations are uniquely trapped.
} 


\section{Tables and Figures}

Table 1: Historical Events Concerning the In Persona Christi Capitis Doctrine

\begin{tabular}{|c|c|}
\hline 391 & St. Augustine first mentions the doctrine \\
\hline 531 & $\begin{array}{l}\text { The Second Council of Toledo decrees that } \\
\text { priestly candidates should be trained } \\
\text { under the eye of the bishop }\end{array}$ \\
\hline $1200-1500$ & $\begin{array}{l}\text { Medieval universities and seminaries } \\
\text { spread throughout Europe }\end{array}$ \\
\hline 1517 & $\begin{array}{l}\text { The Protestant Reformation, in which many } \\
\text { new Christian sects reject the Catholic view of sacraments }\end{array}$ \\
\hline 1545 & $\begin{array}{l}\text { The Council of Trent decrees that every cathedral } \\
\text { should support the teaching of grammar and Holy Scripture } \\
\text { to priestly candidates and poor scholars }\end{array}$ \\
\hline 1556 & $\begin{array}{l}\text { The word "seminary" is first used in the writings } \\
\text { of Cardinal Pole, designating a school exclusively } \\
\text { devoted to the training of the clergy }\end{array}$ \\
\hline 1791 & $\begin{array}{l}\text { Fr. Nagot opens the first seminary in the U.S., } \\
\text { St. Mary's in Baltimore }\end{array}$ \\
\hline 1817 & $\begin{array}{l}\text { After attempts to secularize the seminaries in Germany, } \\
\text { a concordat is signed which preserves the rights of bishops } \\
\text { to open and run seminaries }\end{array}$ \\
\hline 1903 & $\begin{array}{l}\text { Pope Pius X urges bishops to consider the care of their } \\
\text { seminary as their first duty and reforms seminaries in Italy }\end{array}$ \\
\hline 1962-1965 & $\begin{array}{l}\text { The Second Vatican Council clarifies and further develops } \\
\text { Catholic doctrine regarding the sacraments and the priesthood }\end{array}$ \\
\hline 1980-present & Priestly scandals are uncovered in the U.S. Catholic Church \\
\hline
\end{tabular}


Table 2: Weekly Hours Devoted to Prayer by Training and Denomination

\begin{tabular}{c|c|c|c|c} 
& Informal Training & Formal Seminary & All clergy & $\mathbf{N}$ \\
\hline All denominations & 6.60 & 4.40 & 4.80 & 264 \\
Traditional mainline & 5.50 & 3.27 & 3.58 & 86 \\
Conservative mainline & - & 3.44 & 3.55 & 55 \\
Sectarian & 7.56 & 4.62 & 5.92 & 61 \\
Catholic & - & 6.66 & 6.59 & 56
\end{tabular}

Source: Based on Table 1 of Finke and Dougherty (2002), statistics are drawn from a 1994 survey of Milwaukee clergy. A dash (-) represents five or fewer cases reported.

Figure 1: Minimum Seminary Years Required Across Christian Denominations

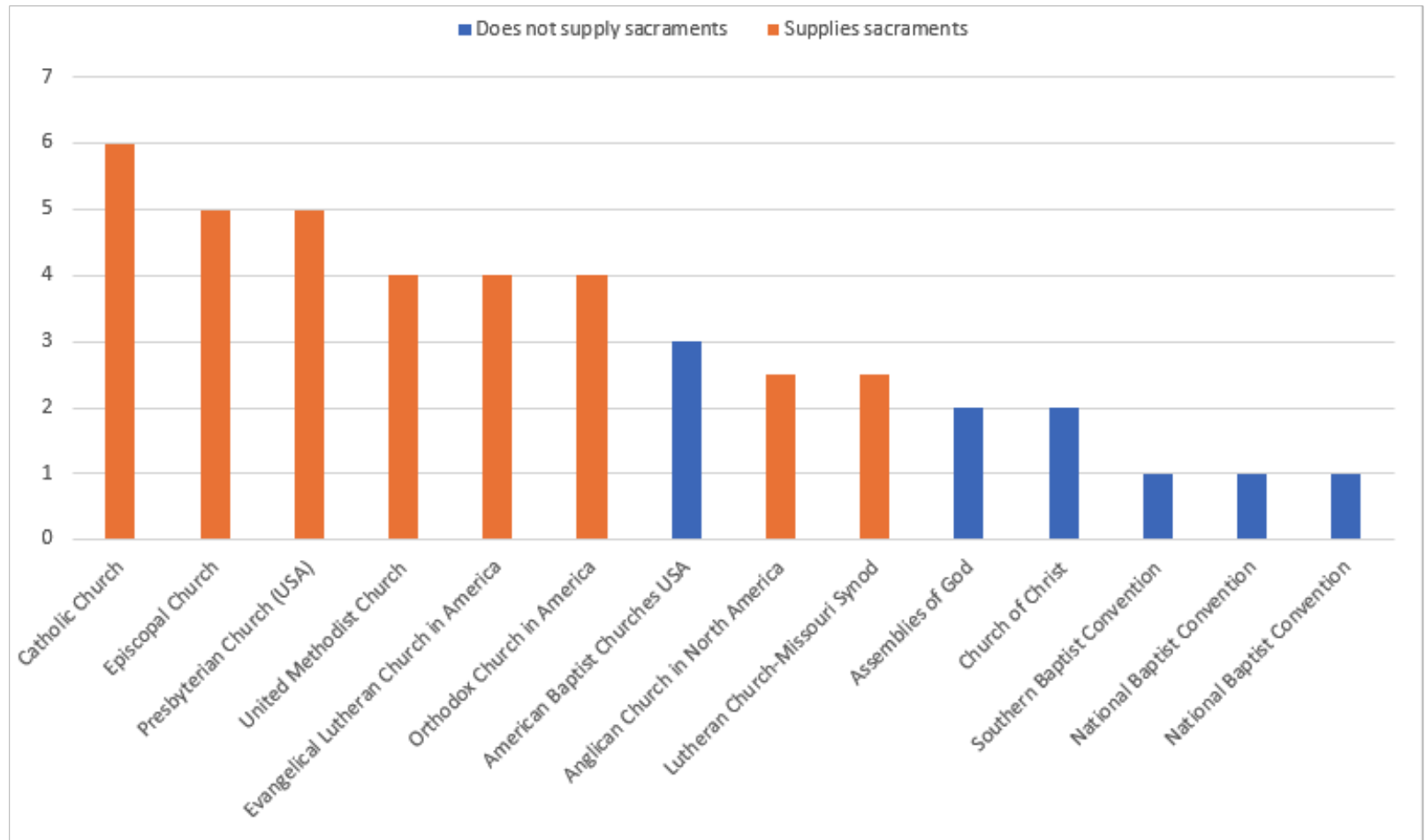

Note: Ten largest Protestant denominations taken from the Pew Research Center's 2014 Religious Landscape Study. Information on seminary length gathered from Gordon Conwell Seminary (https://www.gordonconwell.edu/new-england-mentored-ministry/ wp-content/uploads/sites/26/2019/11/ORDINATION-CHART-2019-updated.pdf). 1 year is assigned to denominations which require no formal training at any level other than the local church. 


\section{References}

(2000). Catechism of the catholic church, 2nd ed. Washington, DC: United States Catholic Conference.

Abbott, E. (2000). A history of celibacy. Simon and Schuster.

Allen, D. W. (1995). Order in the church: A property rights approach. Journal of Economic Behavior Organization, 27(1):97-117.

Arruñada, B. (2009). Specialization and rent seeking in moral enforcement: The case of confession. Journal for the Scientific Study of Religion, 48(3):443-461.

Ault, R. W., Ekelund, R. B., and Tollison, R. D. (1987). The pope and the price of meat: A public choice perspective. Kyklos, 40(3):399-413.

Becker, G. (2011). Challenging merton's protestantism-science hypothesis: The historical impact of sacerdotal celibacy on german science and scholarship. Journal for the scientific study of religion, 50(2):351-365.

Boorstein, M. (Oct 4, 2019). Catholic seminarians are newly speaking out about sexual misconduct $\hat{a}$ and being shunned as a result: "my conscience bothered me. if it meant being thrown out, so be it.". The Washington Post (Online).

Chapman, J. (1909). Donatists. in the catholic encyclopedia. http://www.newadvent.org/ cathen/05121a.htm.

Cholij, R. (1993). Priestly celibacy in patristics and in the history of the church. The Vatican.

Convocation (1562). The articles of religion. https://www. churchofengland. org/prayer-and-worship/worship-texts-and-resources/book-common-prayer/ articles-religion.

Council of Trent (3 March 1547a). Session 23, canons on the sacrament of order. http://www. thecounciloftrent.com/ch23.htm.

Council of Trent (3 March 1547b). Session 7, canons on the sacraments. http://www. thecounciloftrent. com/ch7.htm.

Ekelund, R. B., Hebert, R. F., and Tollison, R. (2002). An economic analysis of the protestant reformation. Journal of Political Economy, 110(3). 
Ekelund, R. B., Hebert, R. F., and Tollison, R. (2004). The economics of the counter-reformation: incumbent-firm reaction to market entry. Economic Inquiry, 42(4):690-705.

Ekelund, R. B., Hebert, R. F., and Tollison, R. (2008). The marketplace of Christianity. MIT Press.

Ekelund, R. B. and Tollison, R. D. (2011). Economic Origins of Roman Christianity. University of Chicago Press.

Ekelund, R. B., Tollison, R. D., Anderson, G. M., Hébert, R. F., and Davidson, A. B. (1996). Sacred trust: the medieval church as an economic firm. Oxford University Press.

Esparza, SJ, C. (2020). How do abuse allegations affect the religious participation of catholics? Job Market Paper.

Ferrero, M. (2011). The infallibility of the pope. Economics of Governance, 12(1):89-99.

Finke, R. and Dougherty, K. D. (2002). The effects of professional training: The social and religious capital acquired in seminaries. Journal for the Scientific Study of Religion, 41(1):103-120.

Francis, P. (2020). Post-synodal apostolic exhortation of the holy father francis, "querida amazonia".

Frazee, C. A. (1988). The origins of clerical celibacy in the western church. Church history, $57: 108-126$.

Gill, A. (2008). Rendering unto Caesar: the Catholic Church and the state in Latin America. University of Chicago Press.

Gill, A. (2020). The comparative endurance and efficiency of religion: a public choice perspective. Public Choice, pages 1-22.

Goebel, G. (2015). Are you called to ordained ministry? https://anglicancompass.com/ are-you-called-to-ordained-ministry/.

Herbermann, C. G. (1913). The Catholic encyclopedia: An international work of reference on the constitution, doctrine, discipline, and history of the Catholic Church, volume 9. Encyclopedia Press.

Holmstrom, B. and Milgrom, P. (1991). Multitask principal-agent analyses: Incentive contracts, asset ownership, and job design. JL Econ. $\&$ Org., 7:24.

Hull, B. B. (1989). Religion, afterlife, and property rights in the high middle ages. 
Hull, B. B. and Bold, F. (1989). Towards an economic theory of the church. International Journal of Social Economics.

Hull, B. B. and Bold, F. (1995). Preaching matters: Replication and extension. Journal of Economic Behavior \& Organization, 27(1):143-149.

Hungerman, D. M. (2013). Substitution and stigma: Evidence on religious markets from the catholic sex abuse scandal. American Economic Journal: Economic Policy, 5(3):227-53.

Iannaccone, L. R. (1998). Introduction to the economics of religion. Journal of economic literature, 36(3):1465-1495.

Kramarek, M. J. and Gautier, M. L. (June 2019). Catholic ministry formation enrollment: Statistical overview for 2018-2019. Center for Applied Research in the Apostolate at Georgetown University, Washington DC.

Lebreton, J. (1910). St. justin martyr. in the catholic encyclopedia. New York: Robert Appleton Company. Retrieved September 27, 2020 from New Advent: http://www.newadvent.org/cathen/08580c.htm.

Leeson, P. T. (2012). Ordeals. The Journal of Law and Economics, 55(3):691-714.

Leeson, P. T. (2013). Vermin trials. The Journal of Law and Economics, 56(3):811-836.

Leeson, P. T. and Russ, J. W. (2018). Witch trials. The Economic Journal, 128(613):2066-2105.

Levada, C. W. (2011). Celibacy and priesthood.

McGrath-Merkle, C. (2020). Fallen failsafes and a revolutionary modern priesthood. Retrieved October 12, 2020 from The Regensburg Forum: https://regensburgforum.com/2020/08/23/fallenfailsafes-and-a-revolutionary-modern-priesthood/.

Pablo II, P. J. (1986). The Theology of Marriage 85 Celibacy: Catechesis on Marriage and Celibacy in the Light of the Resurrection of the Body. Daughters of St. Paul.

Parish, H. (2016). Clerical Celibacy in the West: c. 1100-1700. Routledge.

Pope Paul VI (November 21, 1964). Light of nations, Lumen Gentium. https: //www.vatican.va/archive/hist_councils/ii_vatican_council/documents/vat-ii_ const_19641121_lumen-gentium_en.html.

Schaff, P., editor (1995). Nicene and Post-Nicene Fathers, First Series, Volume 4, St. Augustin: The Writings against the Manicheans, and against the Donatists. Hendrickson Publishers, Inc. 
Schaff, P. and Wace, H. (1895). Leo the Great. Letters. In P. Schaff and H. Wace (Eds.), C. L. Feltoe (Trans.), Leo the Great, Gregory the Great (NPNF Vol. 12a, Letter 167 p. 110). New York: Christian Literature Company.

Schmitt, C. (1996). Roman Catholicism and Political Form. Greenwood Publishing Group.

Stark, R. (2003). One true God: Historical consequences of monotheism. Princeton University Press.

Stark, R. (2007a). Cities of God: The real story of how Christianity became an urban movement and conquered Rome. HarperOne.

Stark, R. (2007b). Cities of God: The real story of how Christianity became an urban movement and conquered Rome. HarperOne.

Stark, R. (2016). Bearing False Witness: debunking centuries of anti-catholic history. Templeton Foundation Press.

The Orthodox Church in America (2020). The sacraments. https://www.oca.org/questions/ sevensacraments/the-sacraments.

Thompson, J. F. (1987). "in persona christi" its significance for the theology of ministerial priesthood in the documents of vatican ii. A Thesis submitted to the Faculty of the Graduate School, Marquette University.

Vieban, A. (1912). Ecclesiastical seminary. in the catholic encyclopedia. http://www . newadvent. org/cathen/13694a.htm.

Warner, C. M. (2019). The politics of sex abuse in sacred hierarchies: A comparative study of the catholic church and the military in the united states. Religions, 10(4):281. 